\title{
An integrated biostratigraphy and seismic stratigraphy for the late Neogene continental margin succession in northern Taranaki Basin, New Zealand
}

\author{
ROCHELLE J. HANSEN \\ PETER J. J. KAMP \\ Department of Earth Sciences \\ The University of Waikato \\ Private Bag 3105 \\ Hamilton 2001, New Zealand
}

\begin{abstract}
Our aim has been to develop an integrated biostratigraphy and seismic stratigraphy for the Pliocene and Pleistocene formations (Ariki, Mangaa, Giant Foresets) in northern Taranaki Basin to better understand the evolution of the modern continental margin offshore central-western North Island, New Zealand. Detailed mapping of seismic reflectors in part of the basin, when compared with correlations of late Neogene stage boundaries between 11 well sections, has highlighted crossover between the datasets. To help resolve this issue, the biostratigraphy of the PliocenePleistocene parts of each of four well sections (Arawa-1, Ariki-1, Kora-1, and Wainui-1) has been re-examined using a dense suite of samples. In addition, the biostratigraphy of seven other well sections (Awatea-1, Kahawai-1, Mangaa-1, Taimana-1, Tangaroa-1, Te Kumi-1, and Turi-1) has been re-evaluated. The crossover is partly attributed to a combination of sampling resolution inherent in exploration well sections, the mixed nature of cuttings samples, and the general scarcity of age-diagnostic planktic foraminifera in the late Neogene formations. The achievement of seismic closure suggests that error in the mapping of the seismic reflectors is not a significant source of the uncertainty (crossover). We have developed a workable time-stratigraphic framework by qualitatively weighting the biostratigraphic data in each of the well sections, thereby identifying the parts of particular well sections with the highest resolution microfossil data and the optimal stratigraphic position of stage boundaries with respect to the mapped seismic horizons/seismic units. Hence, it is possible to assign the known numerical ages for these stage boundaries to reflection horizons/seismic units mapped within the basin. We have applied this information to produce a series of isopach maps for successive stage boundaries that help show the sedimentary evolution of the continental margin succession west of central North Island.
\end{abstract}

Keywords Ariki Formation; Mangaa Formation; Giant Foresets Formation; biostratigraphy; chronostratigraphy; seismic correlation; Taranaki Basin

G04043; Online publication date 28 February 2006 Received 9 November 2004; accepted 16 September 2005

\section{INTRODUCTION}

Northern Taranaki Basin contains a very thick Pliocene-Pleistocene sedimentary succession known as the Giant Foresets Formation, the deposition of which has built up the modern continental shelf and slope offshore from central-western North Island (e.g., Pilaar \& Wakefield 1978). Exploration industry seismic reflection profiles imaging the Giant Foresets Formation display exceptional examples of clinoform development (Beggs 1990), reflecting the successive outstepping of the shelf, slope, and rise as the continental margin has prograded to the north and northwest under the influence of repeated sea-level oscillations. Aside from presenting an outstanding example of continental margin outgrowth under sediment-satiated conditions, with evidence of periodic large-scale mass failure, the Giant Foresets Formation has an important economic role in having loaded and buried the underlying oil-prone Late Cretaceous and Paleogene sediments, thereby potentially generating hydrocarbons (Armstrong et al. 1996; King \& Thrasher 1996).

The quality of the latest open-file industry seismic reflection data is such that fine detail about the internal stratigraphic architecture of the Giant Foresets Formation can be mapped around a grid of seismic reflection data for a substantial part of northern Taranaki Basin. The degree of resolution of the stratigraphic architecture of the Giant Foresets Formation evident in this dataset enables an opportunity to investigate the processes involved in the progradation of a young continental margin, and the rates of these processes. The realisation of this opportunity requires the development of a time-stratigraphic framework for the succession such that approximate numerical ages can be applied to certain horizons. Realistically, biostratigraphic methods are the only ones that can be directly applied to the succession to establish its age.

Within offshore northern Taranaki Basin, 11 exploration wells or holes that have been drilled through the Giant Foresets Formation, and for which well cutting samples are available for biostratigraphic analyses, have been appraised here. For all of these wells, biostratigraphic ages were routinely determined during drilling and have been reported in well completion reports. For some of them, additional biostratigraphic age assessments have been made by other workers and are available in reports held by the Ministry of Economic Development Petroleum Report Library. For four wells (Arawa-1, Ariki-1, Kora-1, and Wainui-1) new biostratigraphic age determinations have been made from closely spaced samples (Hansen \& Kamp 2004a), and are correlated with the existing data for the other well sections.

It might be anticipated that the well-to-well correlations of stage boundaries within the part of the basin investigated here would parallel the numerous seismic reflectors evident in profiles linking the wells. This is, however, not the case. Not uncommonly, particularly for the Pliocene stage boundaries, the correlations appear to cut across seismic reflectors. This is inherently uncomfortable as it suggests that there 

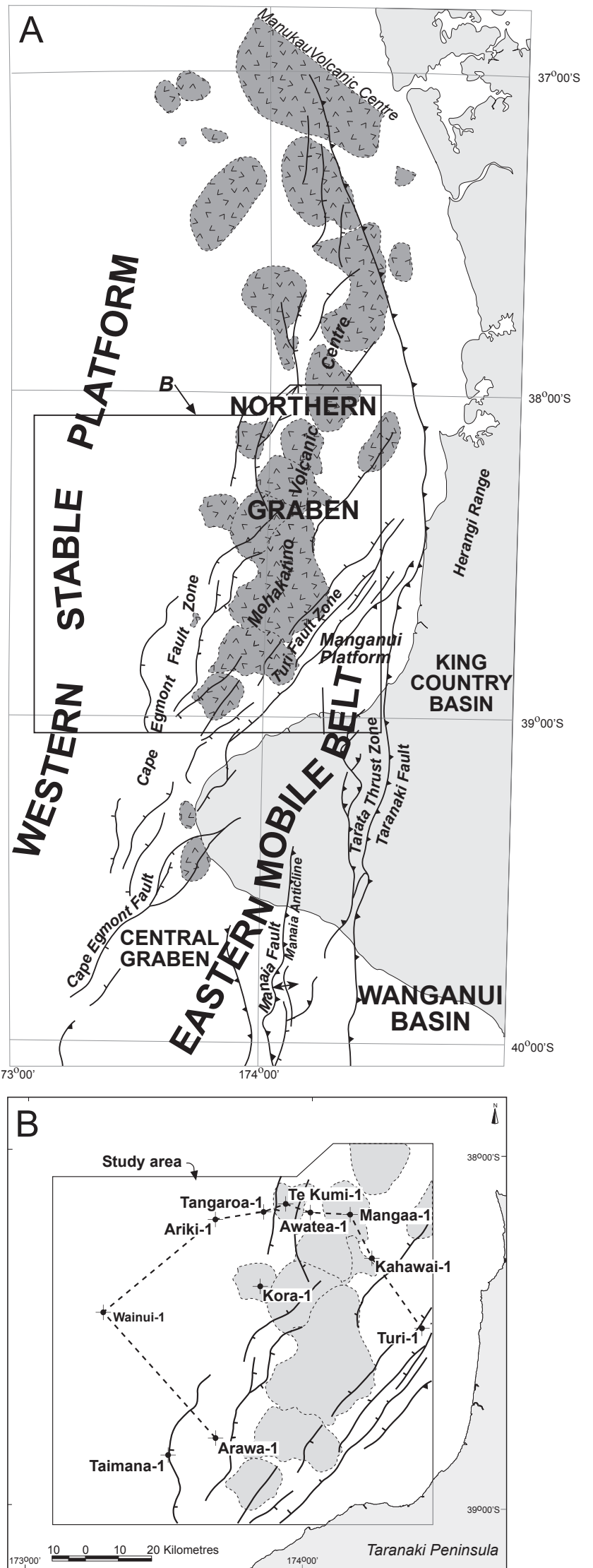

Fig. 1 A, Map of the main structures in Taranaki Basin, modified from King \& Thrasher (1996). The areas coloured grey in the Northern Graben and farther north are middle and late Miocene andesitic volcanic centres now completely buried. B, Location of well sites examined in this study. The dashed line is the line of the chronostratigraphic panel in Fig. 8. are limitations to the robustness and resolution of the biostratigraphy required to be developed to better understand the evolution of the Giant Foresets Formation. In this paper we consider reasons for apparent conflicts between biostratigraphic and seismic correlations between wells. While we can find explanations for a degree of the conflict, uncertainties remain, especially with respect to the biostratigraphy, and to make practical advances in the application of seismic data to regional studies, we suggest a means of developing a coherent integrated seismic stratigraphy and biostratigraphy for this Pliocene-Pleistocene succession.

\section{GEOLOGICAL SETTING}

The Northern Graben and Western Stable Platform of northern Taranaki Basin (Fig. 1) are of particular interest in this study as they contain a very thick (c. $2000 \mathrm{~m}$ ) succession of Giant Foresets Formation (King \& Thrasher 1996; Hansen 2003). The Northern Graben is a NNE-SSW-trending extensional structure that formed during the latest Miocene and Pliocene through back-arc extension related to development of the modern Australia-Pacific plate boundary zone. It is bounded to the east by the Turi Fault Zone and to the west by the Cape Egmont Fault Zone (Fig. 1). Middle-late Miocene andesitic volcanic edifices (now completely buried) are aligned NNE-SSW along the axis of the graben (King \& Thrasher 1996). A late Miocene to early Pliocene marl (Ariki Fmn) underlies the Giant Foresets Formation over the Western Platform, whereas in the Northern Graben an early Pliocene basin floor fan (Mangaa Fmn) (Hansen \& Kamp 2004b) underlies the Giant Foresets Formation. The Giant Foresets Formation in Taranaki Basin makes up a progradational wedge with an internal architecture characterised by classic shelf-slope clinoforms. The siliciclastic sediment making up the wedge was derived from contemporary erosion of the Southern Alps in South Island (Kamp et al. 1989, 2004). The progradation of the Giant Foresets Formation was, however, contemporaneous with the active extension of the Northern Graben. Such was the volume of sediment delivered to this part of the basin during the late Pliocene that it infilled the graben and prograded northwestward onto and over the Western Platform. Correlatives of the Giant Foresets Formation crop out in Wanganui Basin, where they are mapped as the Rangitikei Supergroup (Kamp et al. 2004). The access in outcrop to this succession has enabled improved constraints to be placed on the numerical ages of the late Neogene biostratigraphic stages, many of which have stratotypes in Wanganui Basin (Turner \& Kamp 1990; Beu 2001; Turner et al. 2005).

\section{METHODS}

\section{Biostratigraphy}

The biostratigraphy of 11 well sections in northern Taranaki Basin (Arawa-1, Ariki-1, Awatea-1, Kahawai-1, Kora-1, Mangaa-1, Taimana-1, Tangaroa-1, Te Kumi-1, Turi-1, and Wainui-1; Fig. 1B) were re-evaluated in this study. The late Neogene biostratigraphy in each of four of these wells (Arawa-1, Ariki-1, Kora-1, and Wainui-1) was re-examined in detail using a dense sample spacing (one sample every 5-15 m downhole). Samples were prepared using standard disaggregation and washing preparation techniques, with 


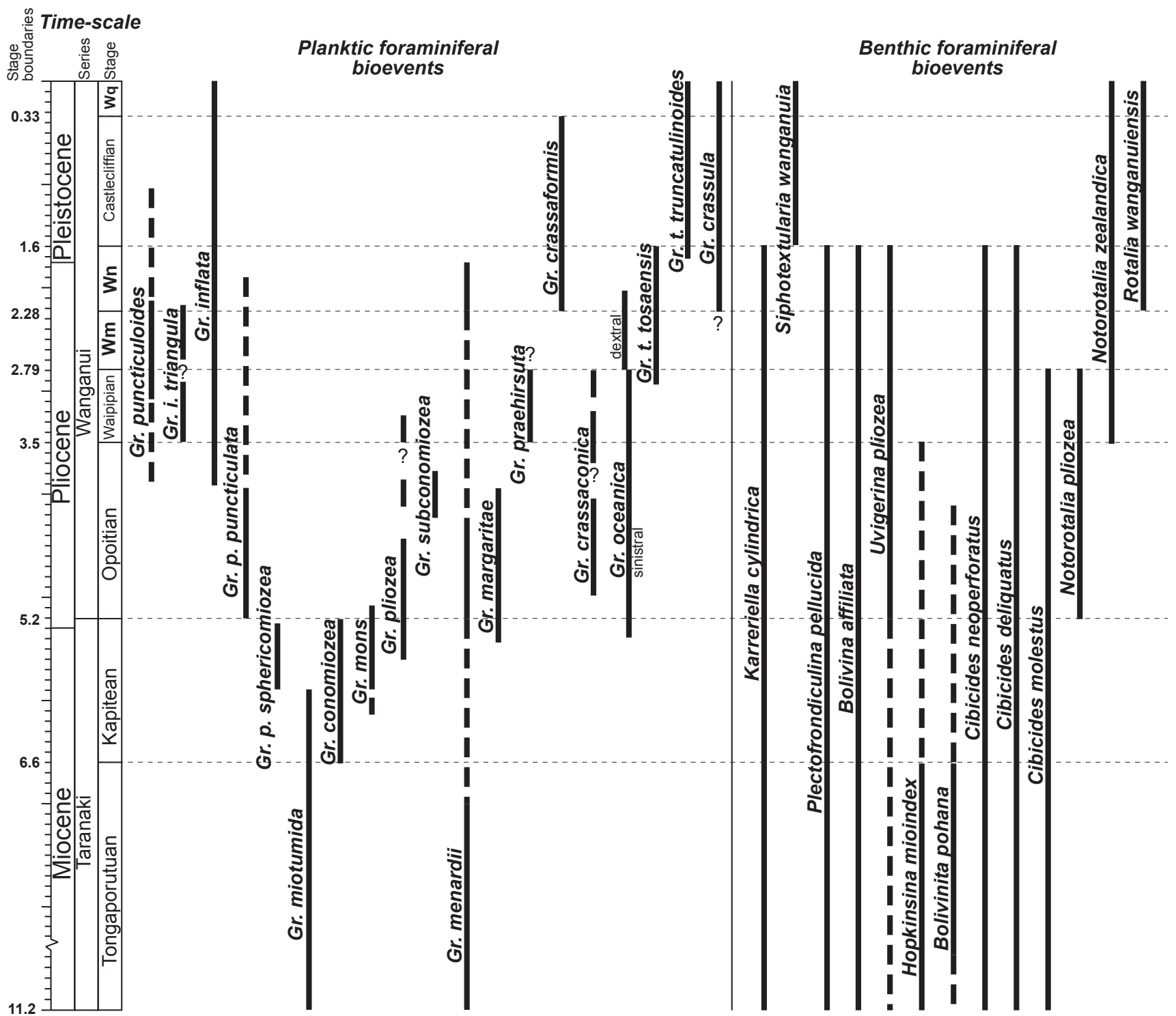

Fig. 2 Time-scale and diagnostic (globorotalid) bioevents used in this study, with subsidiary benthic datums. Time-scale after Morgans et al. (1996) with revisions to the lower Nukumaruan, Mangapanian, and Waipipian Stage boundaries after McIntyre (2001) and unpublished data. Bioevents after Hornibrook et al. (1989), Scott et al. (1990), and Morgans et al. (1996). New Zealand Stage abbreviations: Wm, Mangapanian; Wn, Nukumaruan; Wq, Haweran.

full taxonomic identification of foraminifera in every second downhole sample. Planktic:benthic ratios were calculated for all samples analysed. The extensive data resulting from these analyses, including lowest and highest taxon occurrences, are reported and available in a web-accessible petroleum report (Hansen \& Kamp 2004a) that can be downloaded from the Petroleum Report Library, Crown Minerals, New Zealand Ministry of Economic Development, Wellington (http:// crownminerals.med.govt.nz/petroleum/data/index.html PR no. 2938). This report contains an A0 poster (Enclosure 1) summarising the range of key forminifera against each of the 11 well sections. The associated text comprehensively considers the placement of biostratigraphic stage boundaries in the context of prior biostratigraphic studies, especially the ones that revised the Pliocene and Pleistocene biostratigraphy in Awatea-1 (Strong et al. 1996), Kahawai-1, Mangaa1, Tangaroa-1, and Te Kumi-1 (Waghorn et al. 1996), and Taimana-1 (Crundwell et al. 1992; Scott et al. 2004), all of which used denser sample intervals compared with earlier well completion reports.

Stage determinations were made primarily on the basis of planktic foraminiferal datums, with benthic datums used as a check where possible. This study follows the standard New Zealand Cenozoic stage classification of Morgans et al. (1996), with modification to the age limits of the Mangapanian and Waipipian Stages from McIntyre (2001) and our own work (Fig. 2). We follow Scott et al. (1990) and Morgans et al. (1996) for the chronostratigraphic ranges of key PliocenePleistocene planktic taxa (Fig. 2).

\section{Seismic mapping}

Seismic correlation between the well sections was achieved through analysis of a grid of 25 seismic reflection profiles, part of the high quality P95-series seismic survey acquired by Petrocorp Exploration (1995a) across the northern part of the study area. A further seven older (lower quality) lines (Shell 
BP and Todd Oil Services Ltd 1974; Geco New Zealand 1987; ARCO Petroleum NZ Inc. 1989, 1990; Petrocorp Exploration Ltd 1995b) were used to correlate wells on the Western Stable Platform (Arawa-1, Taimana-1, and Wainui-1) to wells within or on the flanks of the Northern Graben (Ariki-1, Awatea-1, Kahawai-1, Kora-1, Mangaa-1, Tangaroa-1, Te Kumi-1, and Turi-1) (Fig. 1B).

The seismic reflection profiles were interpreted on paper copy, involving the identification of numerous seismic units, many of which were able to be mapped across the study area (Hansen 2003). A test of the resolution and accuracy of the seismic mapping was the achievement of closure of multiple mapped seismic units through the seismic reflection grid. The seismic mapping allowed correlations to be made between exploration wells and therefore provided an independent framework to test biostratigraphic correlations. For each exploration well, seismic sections were converted from time (two-way travel time in milliseconds) to depth (metres below sea level) using velocity functions kindly provided by Geosphere Exploration Ltd (Lower Hutt, New Zealand), to enable the biostratigraphic datums, and especially stage boundaries, to be located onto the seismic reflection profiles passing through well sites. The velocity-depth functions were derived from checkshot data for 14 wells in the northern Taranaki Basin (including Kora-2, -3, and -4), but are valid only to a depth of c. $2.5 \mathrm{~km}$, and do not accurately represent velocities through the buried submarine volcanic piles in the Northern Graben (G. Thrasher pers. comm. 2001).

\section{A TEST OF THE COHERENCY OF WELL-TO- WELL BIOSTRATIGRAPHIC CORRELATIONS IN NORTHERN TARANAKI BASIN}

The re-examination of the biostratigraphy of the well sections in northern Taranaki Basin was undertaken to develop an integrated biostratigraphic and seismic stratigraphy for the Giant Foresets Formation. A feature of the dataset is that in some of the well-to-well correlations, the revised stage boundaries cut across seismic reflection horizons that had been independently correlated between wells via the grid of seismic reflection profiles (Hansen 2003). Seismic reflection horizons mark stratal surfaces, many of which are paleoseafloor surfaces, and are now widely considered within the exploration industry to be time-parallel (e.g., Vail 1987; Cross \& Lessenger 1988; Emery \& Myers 1996). Biostratigraphy tests only that events occur in a particular order. However, although the immigration and extinction of taxa are rarely instantaneous, there should be little significant diachroneity in the first and last appearance datums of the key taxa over the limited extent of the study area. The apparent diachroneity of some of the stage boundaries with respect to seismic reflectors required other explanations and practical choices to be made about which reflection horizons should be mapped across the basin to produce structure contour surfaces. In the end, the horizons selected for structure contour mapping were those for which we had most confidence in the placement of stage boundaries.

To minimise the apparent conflict between biostratigraphic versus seismic correlations, the stratigraphic positions of stage boundaries were re-evaluated in many of the well records. This included re-examination of the foraminiferal slides to check identifications (Arawa-1, Ariki-1, Kora-1, Wainui-1; Hansen 2003), and rechecking of the databases relating foraminiferal content to stratigraphic position for other well sections. The boundaries between stages in each well section were qualitatively assigned a confidence level (high, medium, or low) (Table 1). High to moderate confidence levels were placed on boundaries that were defined by good age-diagnostic criteria. The highest weighting was given to those boundaries that were defined by the first downhole appearance (FDHA) of a particular species rather than the last downhole appearance (LDHA), as the LDHA (or first evolutionary appearance) is often masked by downhole cavings in well sections (e.g., Armentrout 1991). High confidence level boundaries were those able to be confined to a narrow stratigraphic interval downhole. Conversely, low confidence levels were placed on stage boundaries that had poor age-diagnostic criteria and consequently were not able to be located in the well sections with any degree of certainty. It followed that, in redrawing biostratigraphic versus seismic correlations between well sections, stage boundaries that were assigned a high confidence level had little capacity for stratigraphic adjustment, whereas those boundaries designated moderate to low confidence had flexibility to allow some stratigraphic movement to be consistent with the seismic correlations. While the stratigraphic position of the majority of stage boundaries assigned in the prior biostratigraphic reports have remained the same, several

Table 1 Defining criteria for confidence ratings on stage boundary designations.

\begin{tabular}{ll}
\hline Confidence rating & \multicolumn{1}{c}{ Criteria } \\
\hline High & (1) rating given by authors of report used for biostratigraphy \\
or & (2) one or more confidently identified age-diagnostic planktic foraminifera, possibly with \\
supporting benthic foraminifera \\
(1) rating given by authors of report used for biostratigraphy \\
or \\
(2) uncertain of exact placement of boundary because of paucity of fauna between LDHA \\
of a defining planktic foraminifera for overlying stage, and FDHA of a defining planktic \\
foraminifera for the next stage down \\
(1) rating given by authors of report used for biostratigraphy \\
or \\
(2) boundary unable to be clearly defined by any age-diagnostic criteria due to (a) lack of any \\
age-diagnostic faunas, (b) tentative identification, or (c) possibility of cavings. Interpolation \\
of boundary based on what is present, and on seismic correlation with neighbouring wells
\end{tabular}


boundaries (with low to moderate confidence levels) have been adjusted. This has resulted in less crossover of stage boundaries and seismic reflectors (Fig. 3; explanatory text for bioevent codes are given in Table 2) than shown in Hansen (2003)

Biostratigraphic correlations between wells within and on the flanks of the Northern Graben (Ariki-1, Tangaroa-1, Te Kumi-1, Awatea-1, Mangaa-1, Kahawai-1, and Kora-1) are particularly good, with most stage boundaries contained within a narrow spread of seismic units (Fig. 3). However, there is still some crossover, particularly between seismic units of Opoitian-Waipipian age. Much of this crossover can be accounted for by biostratigraphic uncertainty, and possibly by unrecognised errors made in the seismic interpretation. There is very little or no overlap between Miocene and Pliocene strata.

Most biostratigraphic/seismic discrepancy exists in the Waipipian section, especially in correlations amongst Western Platform wells. This is illustrated in Fig. 4 in correlations between Wainui-1 and Taimana-1. Seismic reflectors on profiles between Wainui-1 and Taimana-1 are relatively bold and continuous, and are comparatively easy to trace from profile to profile. In Arawa-1 and Taimana-1, Waipipian strata are confined to seismic units B3-B4. These units are part of a series of large stacked and mounded slope fans (Soenander 1992), which are thickest to the west of Arawa-1 and to the south of Taimana-1. These slope fans pinch out before reaching the vicinity of Wainui-1. At Wainui-1, Waipipian strata are confined to seismic unit A34 only. However, if seismic unit A34 is traced up-dip to the southwest, it occurs well above the seismic units that have been assigned Waipipian age at both Taimana-1 and Arawa-1.
The occurrence of typical specimens of the planktic foraminifera Globorotalia aff. praehirsuta in Wainui-1 between 2000 and $2120 \mathrm{~m}$ below kelly bushing (seismic unit A34) clearly suggests the presence of Waipipian strata from the biostratigraphic criteria reported in Scott et al. (1990), but the seismic correlation from Taimana-1 to Wainui-1 clearly indicates that this unit should be entirely Mangapanian in age. There may be two possible explanations: (1) misidentification of the planktic foraminifera Globorotalia aff. praehirsuta in Wainui-1, or (2) the continuation of Globorotalia aff. praehirsuta into younger (Mangapanian) strata at Wainui-1. Identifications of Globorotalia aff. praehirsuta have been checked (M. Crundwell pers. comm. 1999), suggesting that the first option is not the likely explanation. The Globorotalia aff. praehirsuta record from New Zealand is known to be sporadic (e.g., Scott et al. 1990), and its age range may be poorly defined (B. Hayward pers. comm. 2004). It is considered to be the ancester of Globorotalia hirsuta (Scott et al. 1990), which ranges from the Castlecliffian to Recent, indicating that there may be as yet unrecognised intermediate forms of Mangapanian and Nukumaruan age (B. Hayward pers. comm. 2004). It is therefore possible that the range of Globorotalia aff. praehirsuta may extend farther up the geological column than previously thought to be the case. Hansen (2003) has noted its occurrence in a few samples younger than Waipipian, indicating a series of excursions before Globorotalia aff. praehisuta sensu stricto finally disappeared from the fossil record. Hence, a younger occurrence of Globorotalia aff. praehirsuta in seismic unit A34 in Wainui-1 appears at this stage to be the most plausible explanation for apparent conflict in the biostratigraphic versus seismic correlations between Wainui-1 and Taimana-1/Arawa-1 (Fig. 4).

Table 2 Bioevent used to locate lower stage boundaries (Fig. 3).

\begin{tabular}{|c|c|c|c|c|}
\hline Boundary & Code & Bioevent & $\begin{array}{l}\text { Confidence } \\
\text { in bioevent }\end{array}$ & $\begin{array}{l}\text { Frequency } \\
\text { of event* }\end{array}$ \\
\hline \multirow{3}{*}{$\begin{array}{l}\text { Upper Wn } \\
\text { (intra Wn Stage } \\
\text { boundary) }\end{array}$} & A1 & LDHA/LCO of Gr. truncatulinoides & high & 4 \\
\hline & A2 & $\begin{array}{l}\text { Absence of Gr. truncatulinoides (LDHA not } \\
\text { observed in sampled section) }\end{array}$ & moderate & 1 \\
\hline & A3 & Upper and lower Wn not able to be differentiated & - & 5 \\
\hline \multirow[t]{4}{*}{ Lower Wn } & B1 & FDHA Gr. i. triangulata. & moderate to high & 1 \\
\hline & B2 & Absence criteria only/seismic correlation & - & 8 \\
\hline & B3 & FDHA/presence of Gr. oceanica (D) & moderate & 1 \\
\hline & B4 & FDHA of benthic species Notorotalia pliozea & moderate & 2 \\
\hline \multirow[t]{6}{*}{$\mathrm{Wm}$} & $\mathrm{C} 1$ & FDHA of Gr. crassaconica & moderate & 2 \\
\hline & $\mathrm{C} 2$ & FDHA of Gr. praehirsuta & moderate & 5 \\
\hline & $\mathrm{C} 3$ & Presence of Gr. oceanica (S) & moderate & 2 \\
\hline & $\mathrm{C} 4$ & LDHA of Gr. tosaensis & low & 3 \\
\hline & $\mathrm{C} 5$ & Absence criteria only & - & 1 \\
\hline & C6 & FDHA of benthic species Cibicides molestus & moderate-high & 1 \\
\hline \multirow[t]{3}{*}{$\mathrm{Wp}$} & D1 & FDHA of $G r$. pliozea & moderate & 4 \\
\hline & D2 & FDHA of Gr. subconomiozea & moderate & 2 \\
\hline & D3 & $\begin{array}{l}\text { Presence of Gr. inflata; absence of any other } \\
\text { defining criteria }\end{array}$ & - & 4 \\
\hline \multirow[t]{4}{*}{ Wo } & E1 & FDHA of Gr. sphericomiozea & high & 1 \\
\hline & E2 & FDHA of Gr. miotumida & high & 7 \\
\hline & E3 & Presence of unconformity & high & 5 \\
\hline & E4 & $\begin{array}{l}\text { Interpolated between LDHA of Pliocene-restricted } \\
\text { species and FDHA of Miocene-restricted species }\end{array}$ & low & 1 \\
\hline
\end{tabular}

"Number of wells in which a particular bioevent defines the stage boundary. Boundaries in well sections may be defined by more than one event (Fig. 3). 


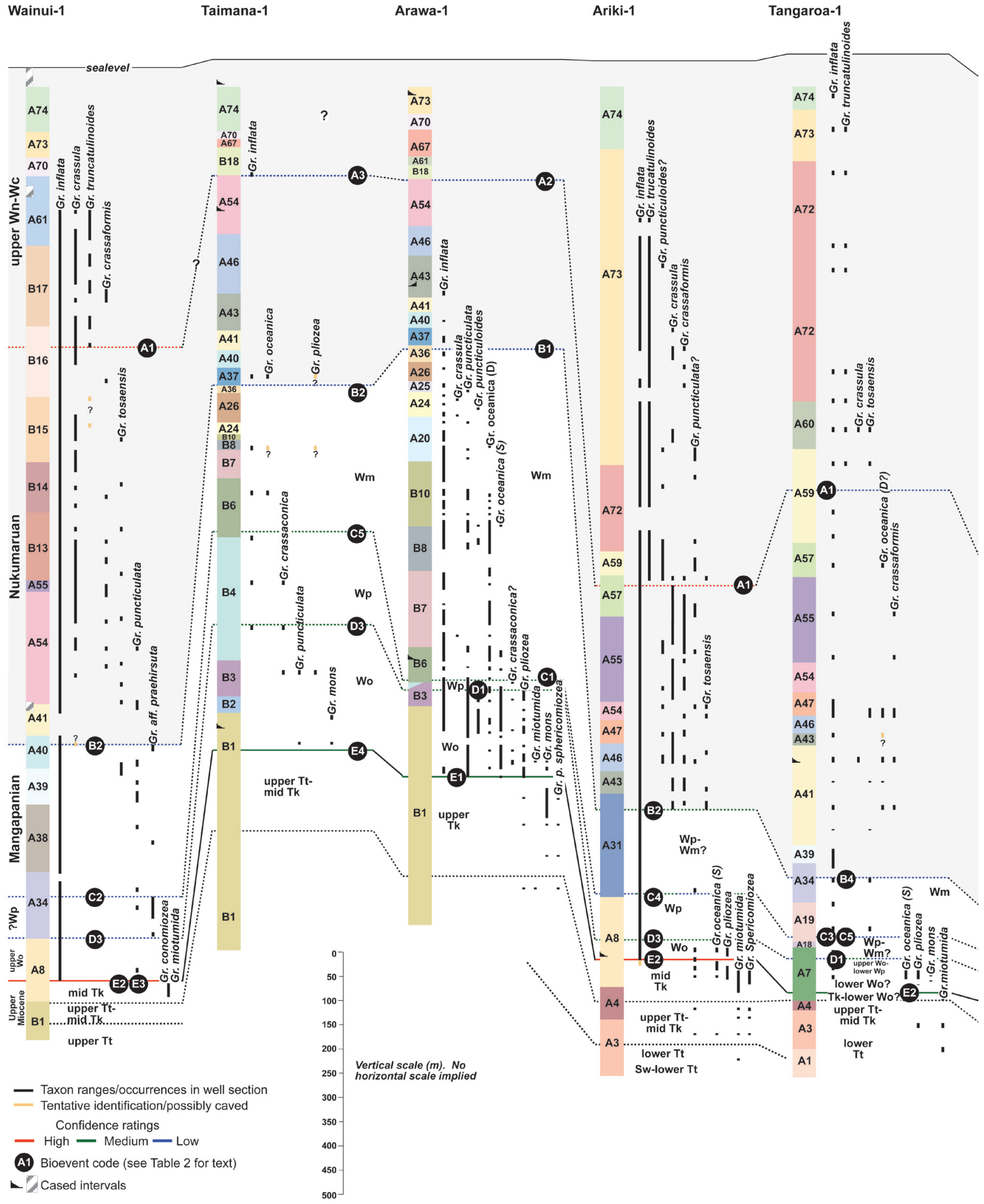

Fig. 3 Late Neogene biostratigraphic events (ranges) used to constrain stage boundaries in relation to seismic units (Hansen 2003) mapped into each well section. The Pliocene-Miocene biostratigraphy of Wainui-1, Arawa-1, Ariki-1, and Kora-1 is from Hansen (2003), Taimana-1 after Hoskins \& Raine (1984) and Crundwell et al. (1992), Mangaa-1, Kahawai-1, Te Kumi-1, and Tangaroa-1 from Waghorn et al. (1996), Awatea-1 from Strong et al. (1996), and Turi-1 from King \& Thrasher (1996). The coded bioevents used to locate stage boundaries are described in Table 2. See Fig. 1B for location of wells. 
Hansen \& Kamp - Integrated stratigraphy, northern Taranaki Basin

Te Kumi-1

Kora-1

Awatea -1

Mangaa-1

Kahawai-1

Turi-1

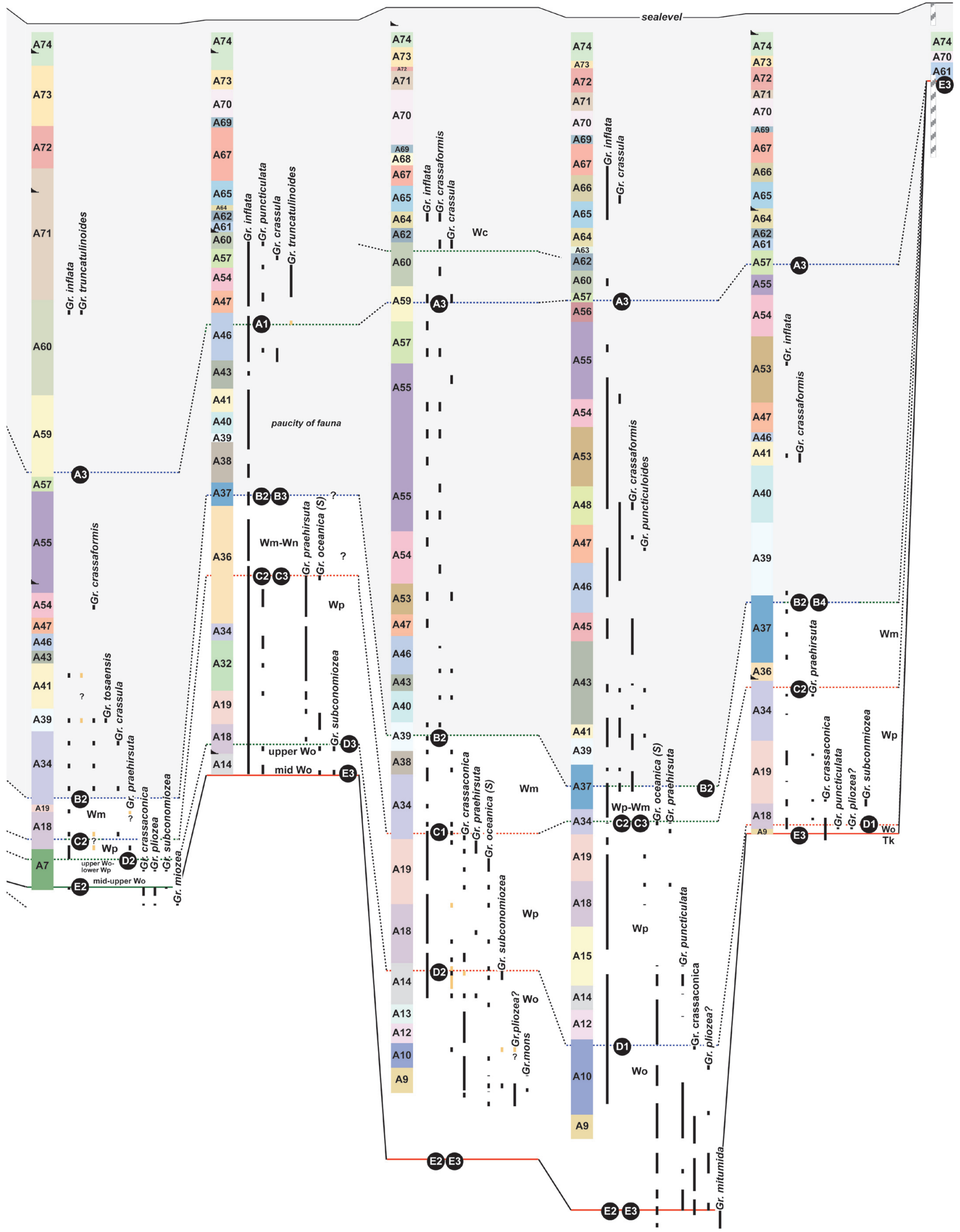




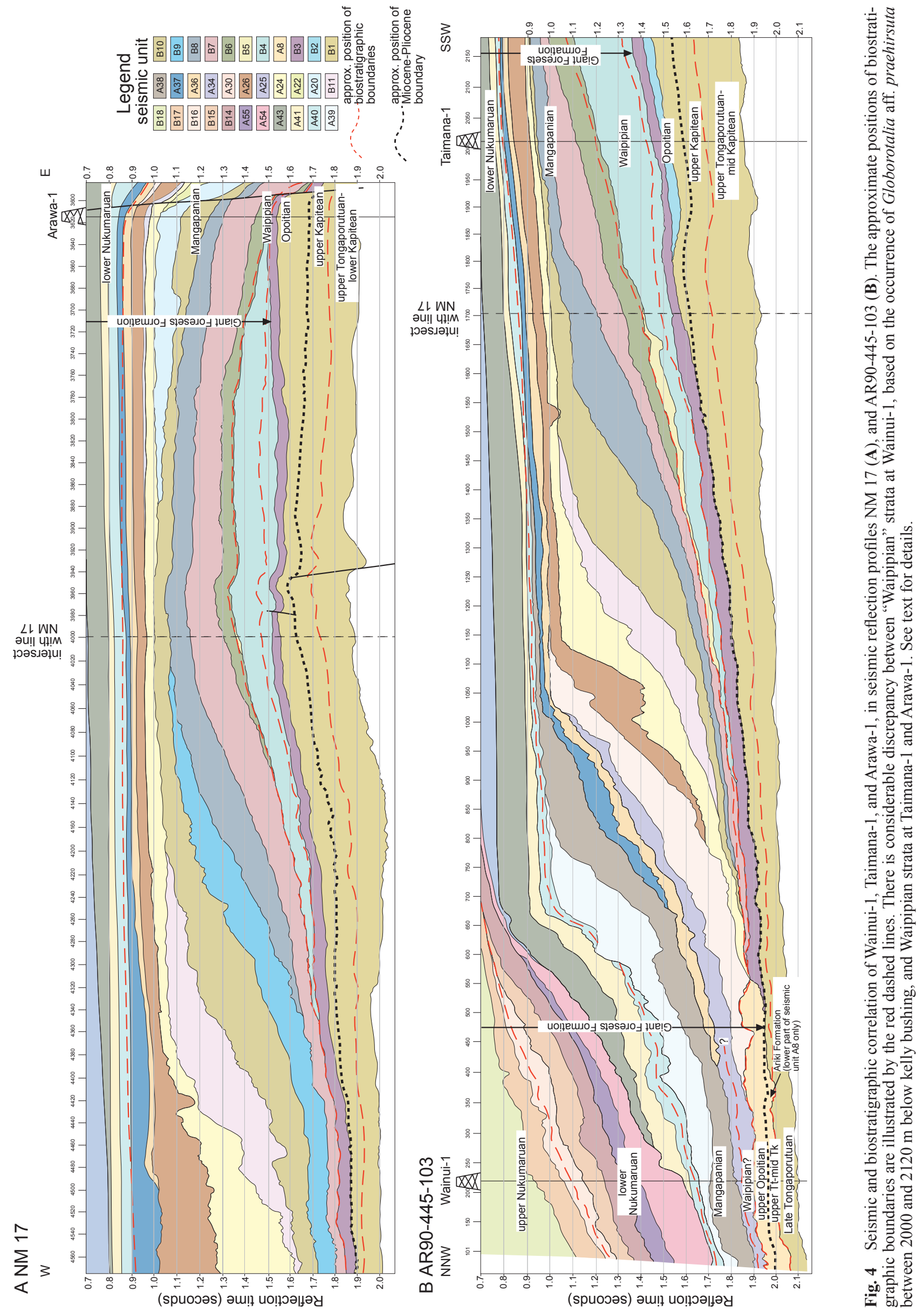


Figure 5 is a summary of the maximum extent of apparent overlap of stages compared with seismic units for the northern Taranaki Basin well sections for two subregions. The overlap shown in Fig. 5 is that which emerges from the independent biostratigraphic analysis of each well section, and prior to any attempt to weight the better constrained stage positions in particular well sections, which we have undertaken as outlined below. Figure 5A relates to the wells in the southern part of the Western Stable Platform (Arawa-1, Taimana-1, and Wainui1), and Fig. 5B relates to the wells in the northern part of the Western Stable Platform and in the northern part of the graben (Ariki-1, Tangaroa-1, Te Kumi-1, Kora-1, Awatea-1, Mangaa1, Kahawai-1, and Turi-1). This division is a consequence of the progradational nature of the Giant Foresets Formation, with many of the seismic units in the southern part of the study area not extending into the northern part. Although overlap of parts of the Pliocene-Pleistocene (Wanganui Series) stages remain, late Miocene Taranaki Series stages do not overlap with Wanganui Series stages. We attribute the post-Miocene overlap to a combination of the following factors.

(1) There are inherent limitations in foraminiferal dating of well cuttings from hydrocarbon exploration wells. These include downhole contamination/cavings, mixing of sediment/chips from various levels within a sampled interval, and coarse sample spacing. The rarity of age-diagnostic taxa in some well sections is also a contributing factor, which is presumed to be due to the neritic overhead environment that existed at several well sites (e.g., Arawa-1; Hansen 2003) during the Pliocene and Pleistocene. Good populations of a particular species are normally not encountered, and stage designations are sometimes limited to the identification of single or juvenile specimens - correct identification of these is sometimes difficult as many species have similar juvenile forms, and there may be several morphological variants within a species population (Bé 1977; Murray 1991). The usual sieve size used during picking of foraminiferal samples (commonly $150 \mu \mathrm{m}$ for well cuttings) may also be a limiting factor. The test size of planktic foraminifera tends to increase with increasing oceanicity (Murray 1976; Hayward 1986), and therefore for sites that may have resided under more neritic conditions (e.g., Arawa-1, Kora-1) the use of larger sieve sizes $(150 \mu \mathrm{m})$ for analyses could have resulted in the significant loss of specimens, and potentially may have created zones that are mistaken as barren of planktic foraminifera.

(2) Another contributor to the level of biostratigraphic resolution may be the poorly known time ranges for rarer planktic taxa (e.g., Globorotalia aff. praehirsuta) in different water masses around New Zealand. While most well sites resided at bathyal water depths throughout the latest Miocene and into the Pliocene before shallowing to shelfal depths, overhead water masses were predominantly neritic to marginal oceanic. This may have affected the distribution in Taranaki Basin of planktic species that prefer fully oceanic conditions (e.g., Globorotalia oceanica; Bé \& Tolderlund 1971), resulting in a more sporadic record. The absolute ranges of some of the more common globorotalid planktic species are also not well constrained. For example, Globorotalia puncticulata is identified as an Opoitian-Waipipian species at DSDP Sites 284 and 593 to the west of New Zealand (Hornibrook 1982; Hoskins 1990), yet typical specimens occur into the Nukumaruan at ODP Site 1125 (east of New Zealand; Sabaa 2000). Similarly, Globorotalia crassaconica is generally considered to be restricted to the Opoitian and Waipipian, but is identified

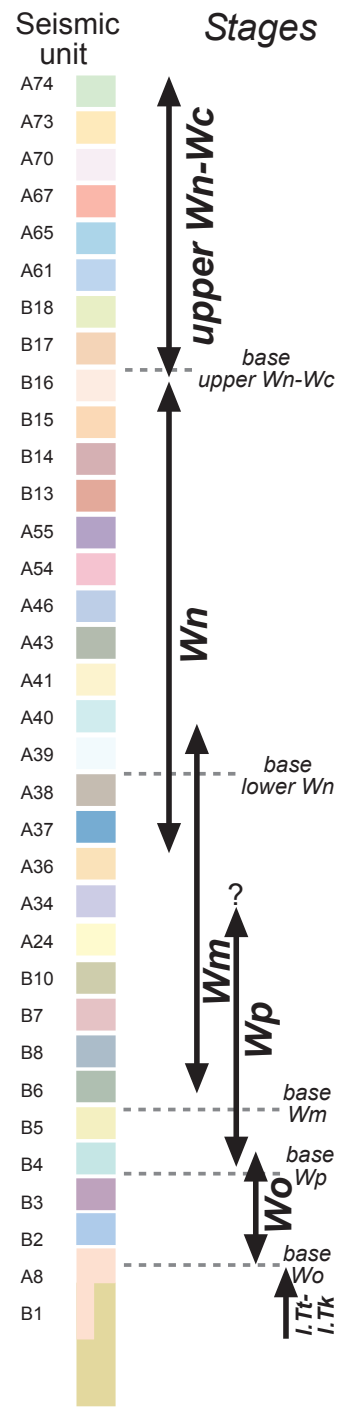

B

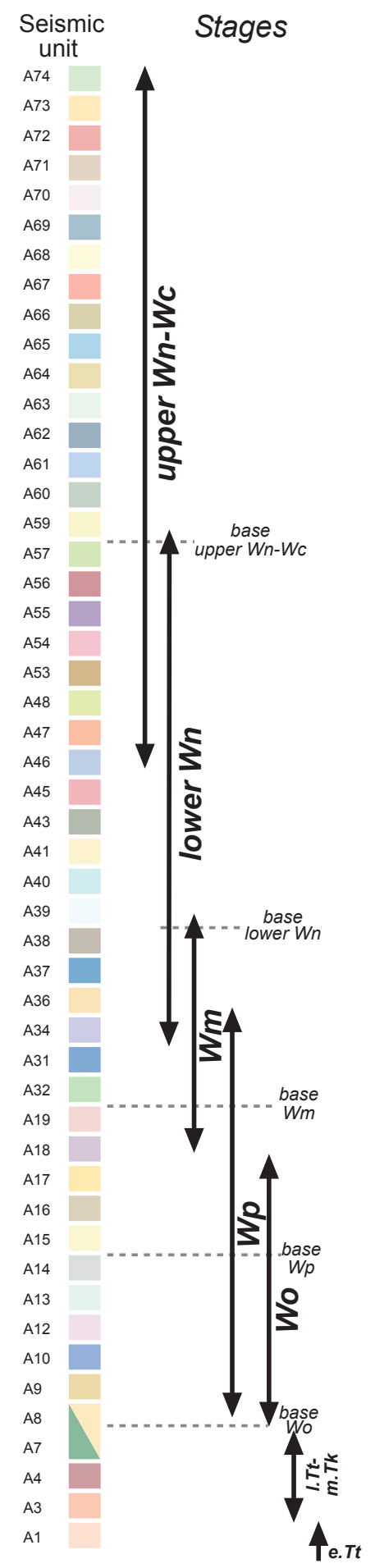

Fig. 5 Correspondence between seismic units and stages resulting from the biostratigraphy in each of 11 wells in northern Taranaki Basin. Region (A) involves wells (Arawa-1, Taimana-1, and Wainui1) in the southern and western parts of the Western Stable Platform; region (B) is for the wells (Ariki-1, Awatea-1, Kahawai-1, Kora-1, Mangaa-1, Tangaroa-1, Te Kumi-1, and Turi-1) in the northern parts of the Western Stable Platform and the Northern Graben. The grey dashed lines mark the adopted (weighted) stage boundaries, and related seismic units, mapped across the basin. See Fig. 6 for detailed well-to-well seismic correlation. 
up into the basal part of the Nukumaruan section at ODP Site 1125 (Sabaa 2000). The diachroneity of foraminiferal bioevents (lowest and highest occurrences) arising from ecological factors such as preferred watermass conditions and biogeographic distribution (e.g., Hayward 1983; Hoskins 1990) is well known (Dowsett 1988). However, this should not be a major factor over short distances such as within Taranaki Basin. There appear to be no overlap issues with Globorotalia inflata or Globorotalia tosaensis.

(3) Seismic mis-correlation along and between seismic reflection profiles, including mis-ties between seismic lines of different origin and vintage, and calculation errors in timedepth conversions (particularly along the axis of the Northern Graben), may be a potential source of the overlap illustrated in Fig. 5. There is also the potential for time-jumping at seismic reflector terminations. However, we consider that these issues have contributed minimal uncertainty as multiple reflectors have been mapped around a substantial seismic grid and closure has been achieved for all seismic units.

\section{INTEGRATED BIOSTRATIGRAPHY AND SEISMIC STRATIGRAPHIC FRAMEWORK FOR NORTHERN TARANAKI BASIN}

A purpose of this investigation has been to develop a timestratigraphic framework for the Giant Foresets Formation and related late Miocene and Pliocene formations in northern Taranaki Basin. The development of a chronostratigraphy requires the determination of numerical ages directly, or via a magnetostratigraphy and correlation to the Geomagnetic Polarity Timescale (e.g., Turner et al. 2005). This is not possible for the Giant Foresets Formation in northern Taranaki Basin, and the best we can do at present is to establish a robust biostratigraphy. Numerical ages can nevertheless be assigned to stage boundaries where these are known for other sites, such as the Pliocene/Pleistocene stage boundaries in Wanganui Basin (Turner \& Kamp 1990; Cooper 2004; Turner et al. 2005). In addition, in northern Taranaki Basin, seismic reflection horizons and units can be mapped in detail and these are regarded as isochronous surfaces and units (e.g., Mitchum et al. 1977; North American Commission on Stratigraphic Nomenclature 1983). This independent means of correlation adds value to the biostratigraphy, the challenge being to identify which of the well sections, or combination of well sections, have the best defined biostratigraphy and stage designations to age-calibrate the seismic correlations between the well sections and throughout the study area. The approach we have taken has been to re-examine the faunal content in key wells to produce a revised biostratigraphy, and to re-evaluate the biostratigraphy in other wells. While this has identified crossover between biostratigraphic correlations and seismic horizons and units, we show below that the weighting of the biostratigraphic data identifies in which wells particular stage boundaries are best established, thereby enabling numerical ages to be assigned to those horizons. Thus, we have produced an integrated biostratigraphic and seismic stratigraphic framework for late Neogene strata in northern Taranaki Basin, which approximates a chronostratigraphy.

Biostratigraphic dating of well cuttings has inherent limitations, as outlined above. This determines the resolution with which particular datums and stage boundaries can be located in a well section. The resolution of biostratigraphic dating in the muddy Giant Foresets Formation, which comprises the upper $2 \mathrm{~km}$ of overburden, is usually not a priority, and typically a minimum of samples are analysed, which compounds the resolution problem associated with the analysis of cutting samples. The different levels of sample spacing and hence biostratigraphic resolution generated in the different studies of the Giant Foresets Formation has been a major factor leading to the apparent overlap of the late Neogene stages illustrated as the composite biostratigraphy in Fig. 5. Hence, we have more heavily weighted the biostratigraphic data in well sections where there is higher confidence in the placement of stage boundaries, using the criteria previously discussed (particularly in Ariki-1, Kora-1, Awatea-1, and Kahawai-1). Less weight has been placed on the biostratigraphic data in Arawa-1, Tangaroa-1, and Te Kumi-1. This has resulted in minor to significant (up to c. $170 \mathrm{~m}$ ) shifts in the notional position of the biostratigraphic stage boundaries as seismically mapped throughout the study area from the wells where the stage boundaries are best located (Fig. 3). Accordingly, the stage boundaries illustrated in Fig. 6 are termed "Integrated Biostratigraphic-Seismic Stratigraphic Boundaries", or IBSB.

For the upper Nukumaruan (to Recent) IBSB boundary, the top of seismic unit A57 (or in its absence the next lowest horizon) was chosen to correspond to the intra-stage IBSB boundary. We have the highest confidence in placing this intra-stage IBSB in Ariki-1. This seismic unit also has the advantage that it is the most extensive of any of the units associated with this intra-stage IBSB. This unit, however, does not extend to the Western Stable Platform well sites (Wainui1, Taimana-1, and Arawa-1). At Wainui-1, the seismic reflector horizon picked as corresponding to this boundary is (top) B16, and where this pinches out, A55 or A54 (A54 at both Taimana-1 and Arawa-1) are used for correlation. This seismic correlation is acceptable within the constraints of the biostratigraphic data for the intersected wells on the Western Stable Platform (Wainui-1, Taimana-1, and Arawa-1).

There is low confidence generally in the placement of the lower Nukumaruan IBSB. This boundary is picked with a moderate level of confidence in Awatea-1 (within seismic unit A39), and with moderate to low confidence at both Mangaa-1 and Kahawai-1 (upper part of A37). It is picked with a moderate degree of confidence at Ariki-1 also (near top of seismic unit A31). However, as seismic unit A31 (e.g., Ariki-1) is of limited extent, the base of seismic unit A39 (top seismic unit A38) is the main reflector used in correlation across the basin, including the Western Stable Platform.

In most well sections, the Nukumaruan/Mangapanian boundary position is uncertain, and the Mangapanian Stage is very poorly differentiated, often being based on absence criteria. However, the lower boundary is placed with high confidence in Kahawai-1 and Awatea-1 (within seismic unit A34), Kora-1 (seismic unit A36), and with moderate confidence in Taimana-1 (lower part of seismic unit B6) and Arawa-1 (lowermost part of seismic unit B6) on the Western Stable Platform. The base of the Mangapanian Stage falls within seismic unit A34 (with moderate confidence) at Wainui-1 and Mangaa-1. In several cases, this lower horizon was proximal to the top of seismic unit A19, which was subsequently chosen as the Mangapanian IBSB, with seismic units B5 (very limited extent)/B4 being chosen for the Western Stable Platform wells. The adoption of seismic units for this boundary has resulted in a significant downward shift of the Mangapanian 
IBSB in several wells (e.g., Kahawai-1, c. 115 m; Kora-1, c. $250 \mathrm{~m}$ ) compared with the biostratigraphically determined placement of this stage boundary, and upward in Te Kumi-1 (c. $85 \mathrm{~m}$ ) and Tangaroa-1 (c. $75 \mathrm{~m}$ ), with only minimal shifts in most other wells.

High confidence levels have been assigned to the lower boundary of the Waipipian Stage at Awatea-1 and Kahawai-1, with the stage boundary falling within seismic units A14 (near top) and A18 (near base), respectively. Moderate confidence levels have been assigned to this boundary in several other wells, including Taimana-1 (lower part of seismic unit B4), Arawa-1 (upper part of seismic unit A3), Ariki-1 (lower part of seismic unit A8), Kora-1 (lower part of seismic unit A18), and Mangaa-1 (uppermost part of seismic unit A10). Given the high confidence rating for this boundary in Awatea-1, the position of the boundary in Kahawai-1 (very close to the base of A18), and the Opoitian age of seismic unit A14 at Kora-1, the top of seismic unit A14 (or next lowest unit) was chosen for the lower Waipipian IBSB. This has resulted in the minimal need for movement of the lower Waipipian boundary in most well sections, and results in a coherency between biostratigraphic and seismic correlations for wells on the flanks of the Northern Graben. On the Western Stable Platform the lower Waipipian IBSB aligns with the top of seismic unit B3 (or next lowest unit). This suggests that there are no Waipipian strata at Wainui-1, and that most of the Waipipian Stage strata on the Western Stable Platform are associated with the large fan mounds that accumulated in the vicinity of Taimana- 1 at this time (Waipipian).

All of the wells have moderate to high confidence ratings in relation to placement of the lower boundary of the Opoitian Stage (approximately the Miocene/Pliocene boundary). This boundary in most cases is marked by a paraconformity, and at several sites (e.g., Ariki-1, Wainui-1, Tangaroa-1, and Te Kumi-1) is associated with the Ariki Formation. Seismic units were not mapped across the whole study area at the level of the Kapitean/Opoitian boundary. In the Northern Graben, a single seismic reflector (unnamed) is mapped as the Kapitean/Opoitian boundary (Mangaa-1, c. 2766 m below kelly bushing; Awatea-1, c. 2675 m below kelly bushing). In much of the graben this boundary corresponds to the sedimentary/volcanic contact. On the western flanks of the graben, the Kapitean/Opoitian boundary corresponds to the base of seismic unit A7 (Tangaroa-1, Te Kumi-1), or within seismic unit A8 (Ariki-1, Wainui-1), and on the eastern flanks of the graben it corresponds to the base of seismic unit A9 (Kahawai-1), which is an unconformity.

In summary, Fig. 5A,B show the base of the stage boundaries in relation to the seismic units as adopted in this study for mapping. Figure 6 shows in more detail, and with respect to each well, how those boundaries are mapped from well-towell in relation to the seismic units.

This procedure has enabled the Giant Foresets Formation and the underlying Mangaa Formation to be subdivided into five biostratigraphic units for a sedimentary succession that accumulated across $5 \mathrm{~m}$.y. This is a reasonably detailed biostratigraphic subdivision. It has to be remembered that were it not for the ability to map an order of magnitude higher resolution seismic units around the grid of seismic reflection profiles, the overlap in stage boundaries we have identified here would not have been evident, and any overlap of stages would possibly have been lost in the seismic mapping. While this provides some perspective, the issue remains that we have been motivated to develop the best chronostratigraphic template possible to be overlain on the seismic mapping to transfer (approximate) numerical ages for stage boundaries, so that rates of processes can be estimated for this remarkable continental margin succession. Uncertainties remain, however, and we think that these relate to a general rarity of age-diagnostic taxa in the paleodepositional setting, involving marked shallowing from basin floor to slope to shelf morphological zones, and associated switching from oceanic to neritic water masses during accumulation of the Giant Foresets Formation.

\section{ISOPACH MAPS}

Basin analysis using seismic reflection datasets typically involves the production of structure contour maps and derivative isopach maps. These can be useful in defining the regional stratigraphic architecture, in assessment of a basin's burial history, for complementing geohistory analyses of well sections, and for inferring likely hydrocarbon migration pathways. The Giant Foresets Formation has a particular pattern of burial as the shelf-slope margin prograded rapidly northwestward, successively loading in a northwest direction the underlying Late Cretaceous through middle Neogene succession. In addition, the Giant Foresets Formation prograded into and across the Northern Graben concurrent with its extension (Hansen \& Kamp 2004b)

Structure contour maps could be drawn at the level of any of the seismic unit boundaries mapped through the grid of seismic reflection profiles in northern Taranaki Basin, but these are best prepared for horizons for which numerical ages are available, which means the stage boundaries. We have done this for the stage boundaries identified within the Giant Foresets Formation and within the Mangaa Formation. The derivative isopach maps are illustrated in Fig. 7. We have produced one map for the combined Waipipian and Mangapanian Stages, and have produced a map for each of the lower Nukumaruan Stage, and the upper Nukumaruan-Recent interval.

The isopachs maps in Fig. 7 show the shifting location of depocentres with accumulation of the Mangaa Formation and Giant Foresets Formation in northern Taranaki Basin. This complements and extends the isopach maps prepared by Soenander (1992) for the southern part of the study area. The depositional patterns within the Giant Foresets Formation are clearly related to the progradation of the modern continental margin into northern Taranaki Basin during the Pliocene and Pleistocene. During the early Pliocene (Opoitian, Fig. 7A) deposition was focused in the southern part of the study area. The progradational front moved into the vicinity of Arawa-1 and Taimana-1 during the early-late Pliocene (Waipipian and Mangapanian, Fig. 7B). This was in the form of large mounded slope fans, evident on seismic lines as well as isopach and structure contour maps, consistent with the seismic mapping of Soenander (1992). Throughout the Mangapanian and into the lower Nukumaruan (Fig. 7C), the progradational front moved rapidly to the north and west through and across the Northern Graben to form a distinct shelf-slope depositional front. During the late Nukumaruan-Recent (Fig. 7D), the progradational front straightened and reached the present position of the shelf-slope break. Even during the late Nukumaruan-Recent, broad subsidence persisted in the Northern Graben, influencing sedimentation and trapping a proportion of the sediment flux sourced to the margin from the south. 


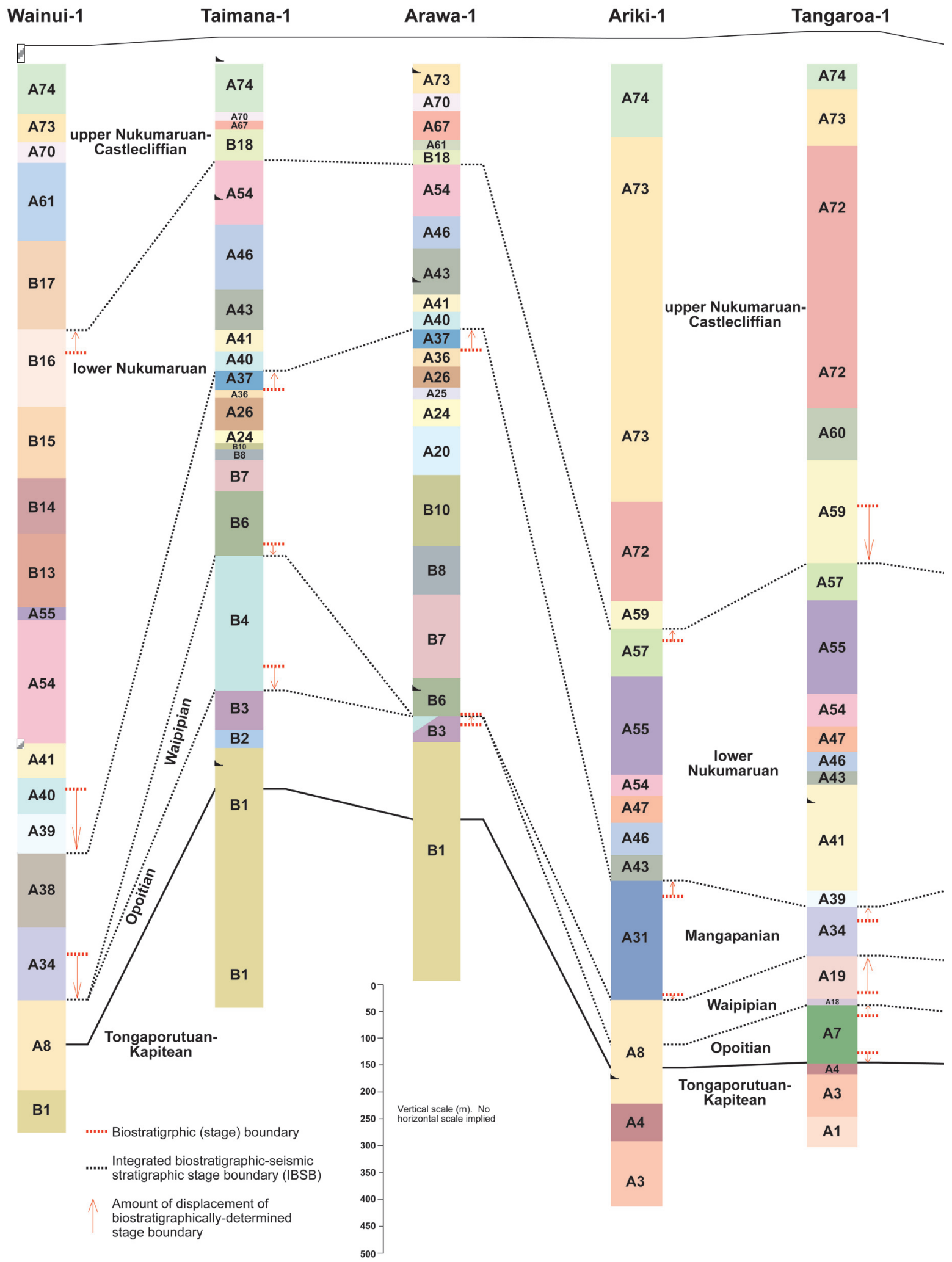

Fig. 6 Stratigraphic positions in 11 northern Taranaki Basin exploration holes of Integrated Biostratigraphic-Seismic Stratigraphic Boundaries (IBSB) adopted from the analyses undertaken in this study in relation to seismic units mapped through the grid of seismic reflection data. The red arrows indicate the amount of displacement of the biostratigraphically determined stage boundaries. The Miocene/Pliocene boundary occurs below the mapped seismic units in several wells within the Northern Graben. See Fig. 1B for the location of exploration wells. 
Hansen \& Kamp —-Integrated stratigraphy, northern Taranaki Basin

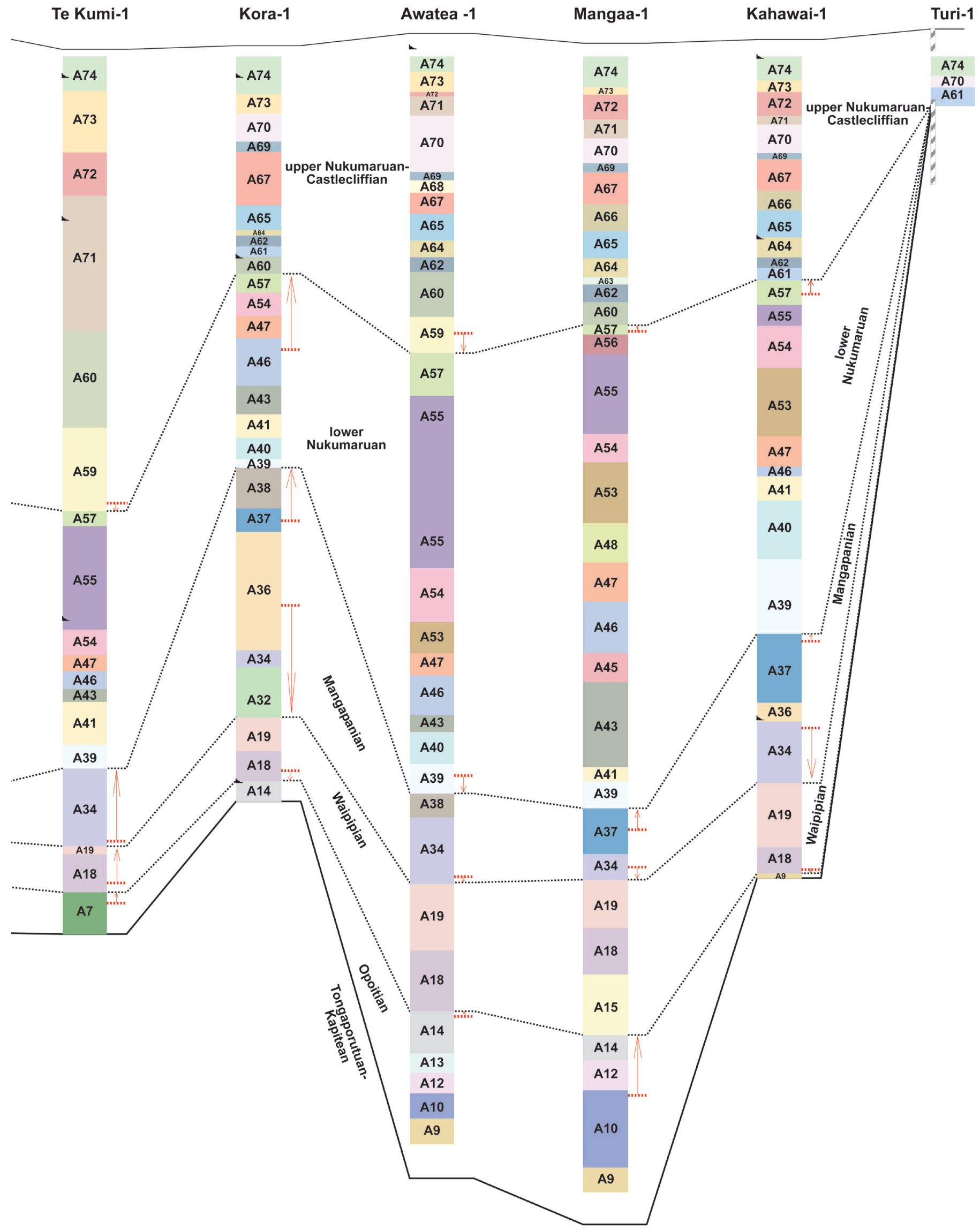




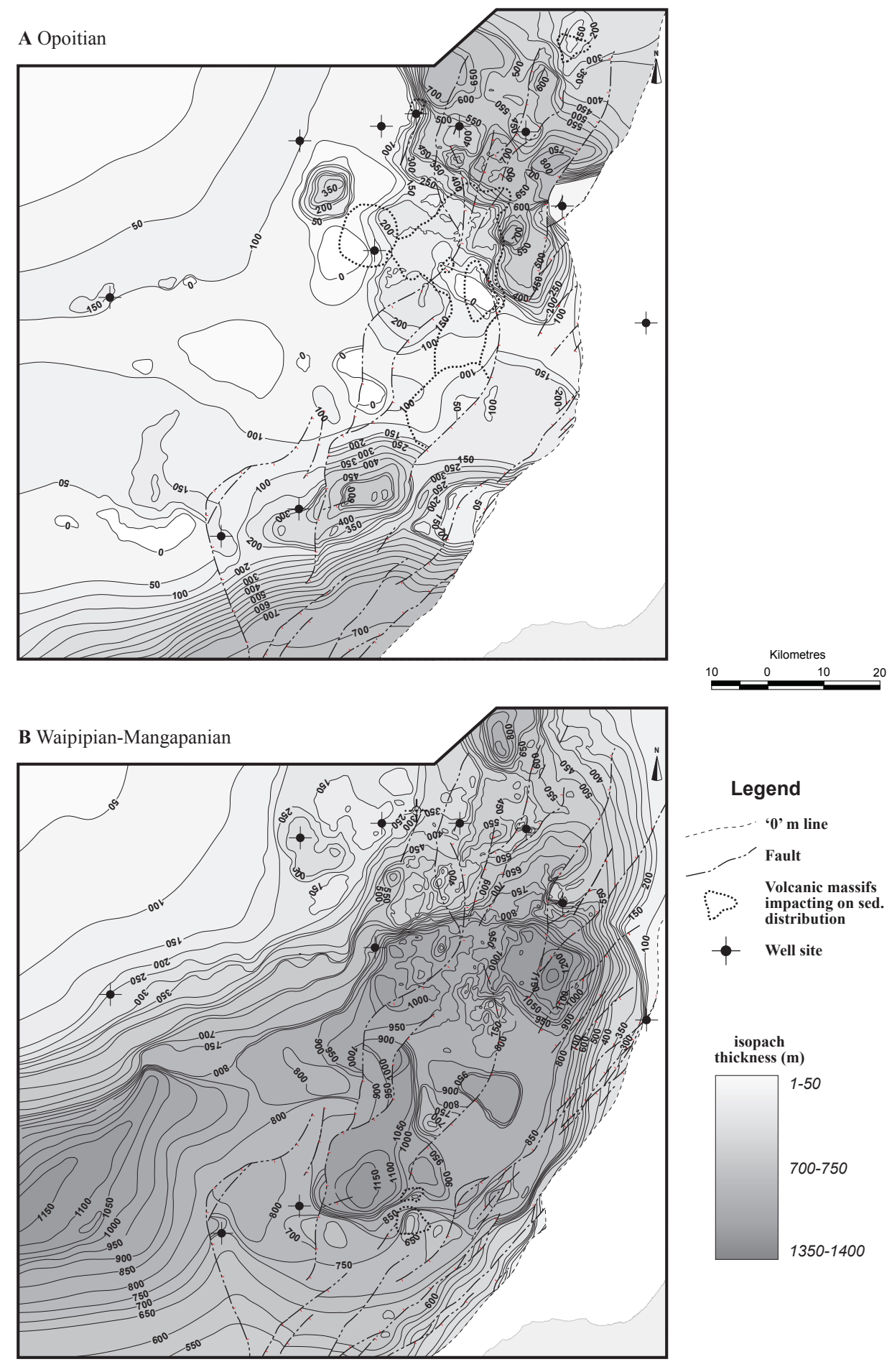

Fig. 7 Isopach maps for northern Taranaki Basin drawn for each of the Opoitian(A), Waipipian-Mangapanian (B), lower Nukumaruan (C), and upper Nukumaruan-Recent (D) intervals. Contours have been drawn at $50 \mathrm{~m}$ thickness intervals. ' 0 ' $\mathrm{m}$ line is the point at which section is no longer present as a result of postdepositional erosion.

A consequence of the compromises that had to be made in picking the biostratigraphic stages in well sections in relation to the mapped seismic units is that at most well sites there will be differences between the thicknesses of section associated with stages, as determined for particular wells from foraminiferal analyses, versus the thicknesses resulting from the generation of isopach maps. These differences are recorded in Table 3 . The magnitude of the differences is greater for the wells for which relevant stage boundaries have not been well constrained, and which have predominantly low to moderate confidence ratings (e.g., Mangaa-1, Tangaroa-1), compared with the well sections for which we assess the biostratigraphy is relatively well defined, and which have predominantly moderate to high confidence ratings (e.g., Awatea-1, Kahawai-1). In the former case the magnitude of differences is as much as $150 \mathrm{~m}$, but in the wells with better biostratigraphic resolution, the differences are in the order of $100 \mathrm{~m}$ or less for all stage boundaries, with many stages having approximately the same thickness both in the well section and isopach map. This suggests that the approach adopted here to develop a time-stratigraphic framework, in the absence of numerical dating methods, can be used to construct meaningful maps of sediment thickness. 
Fig. 7 (continued)
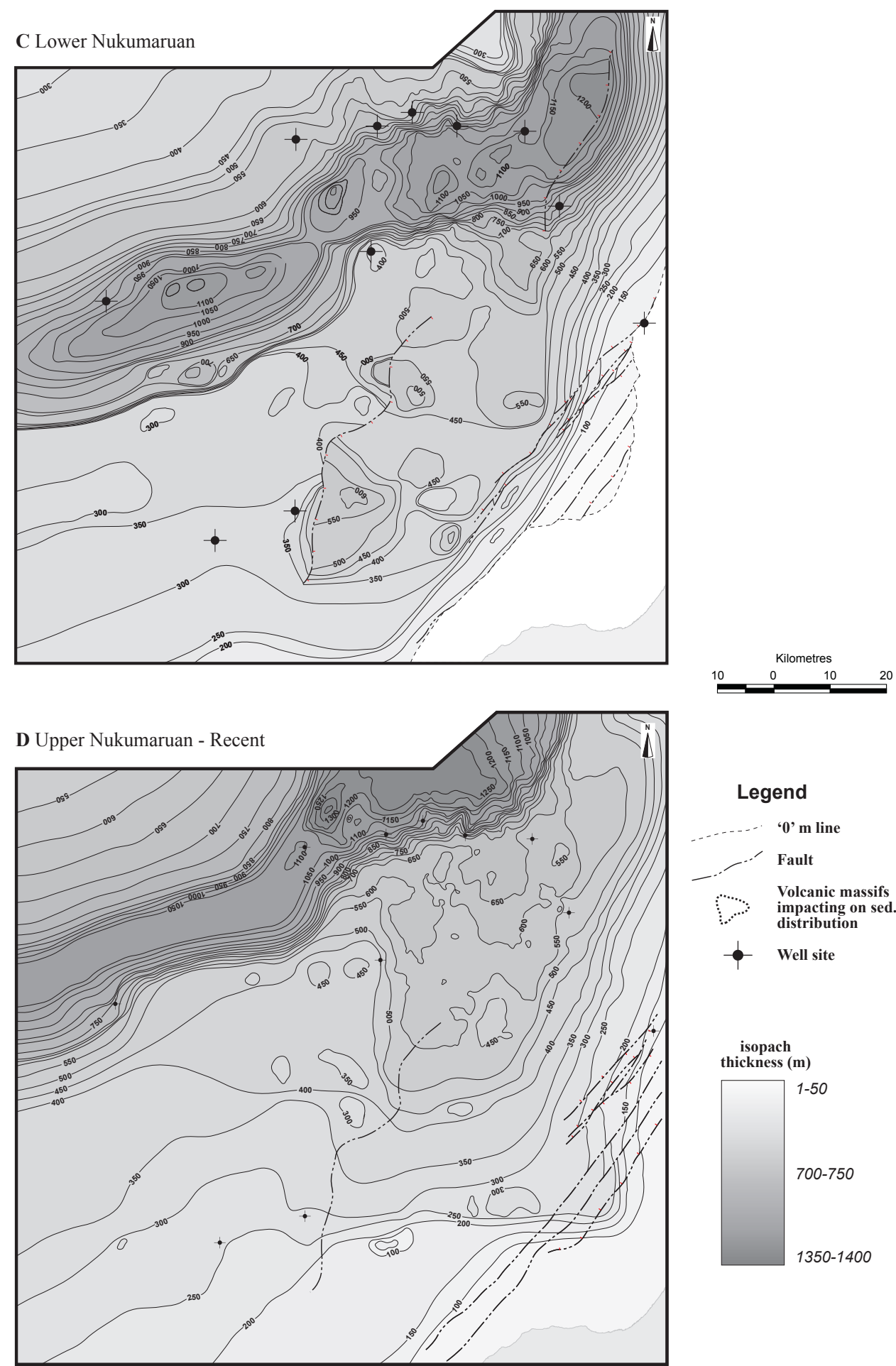

\section{TOWARDS A CHRONOSTRATIGRAPHY FOR NORTHERN TARANAKI BASIN}

The revised biostratigraphy reported here for the well sections in the northern part of Taranaki Basin, together with detailed seismic mapping, has enabled an integrated biostratigraphic and seismic stratigraphic framework to be developed for the late Miocene through to Pleistocene formations in the basin (Fig. 8). The time-stratigraphic framework, while not a definitive chronostratigraphy, is nevertheless robust because (1) the correlation between well sections and throughout the study area is based on the mapping of high resolution seismic horizons, and (2) ages can be assigned via the placement of stage boundaries in well sections that have the best biostratigraphic resolution. We have been careful to weight the uncertainty of the biostratigraphic datums. What falls out of this approach is the apparent crossover of the stage correlations with seismic correlations. In many cases, there is actually sufficient uncertainty in the biostratigraphy to accommodate a downward or upward shift to the stratigraphic position indicated by seismic correlation. Where greater movement is required, we consider 


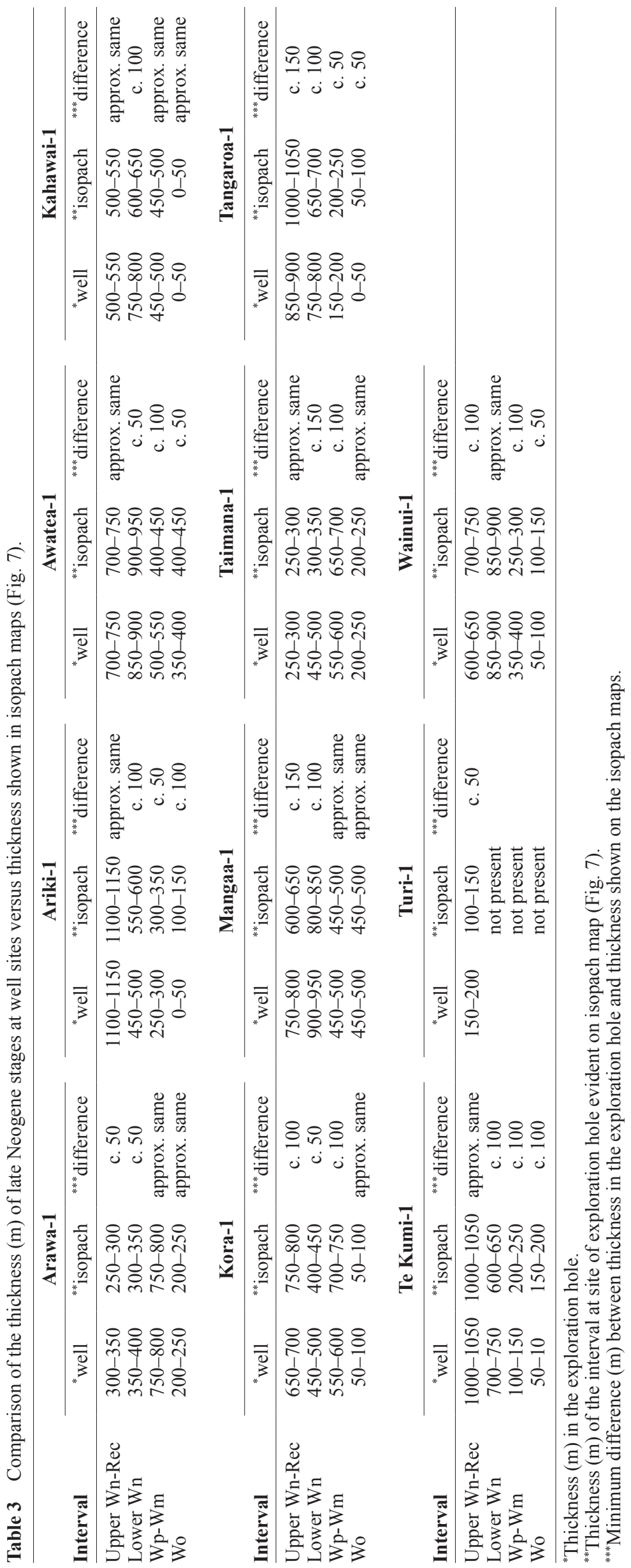




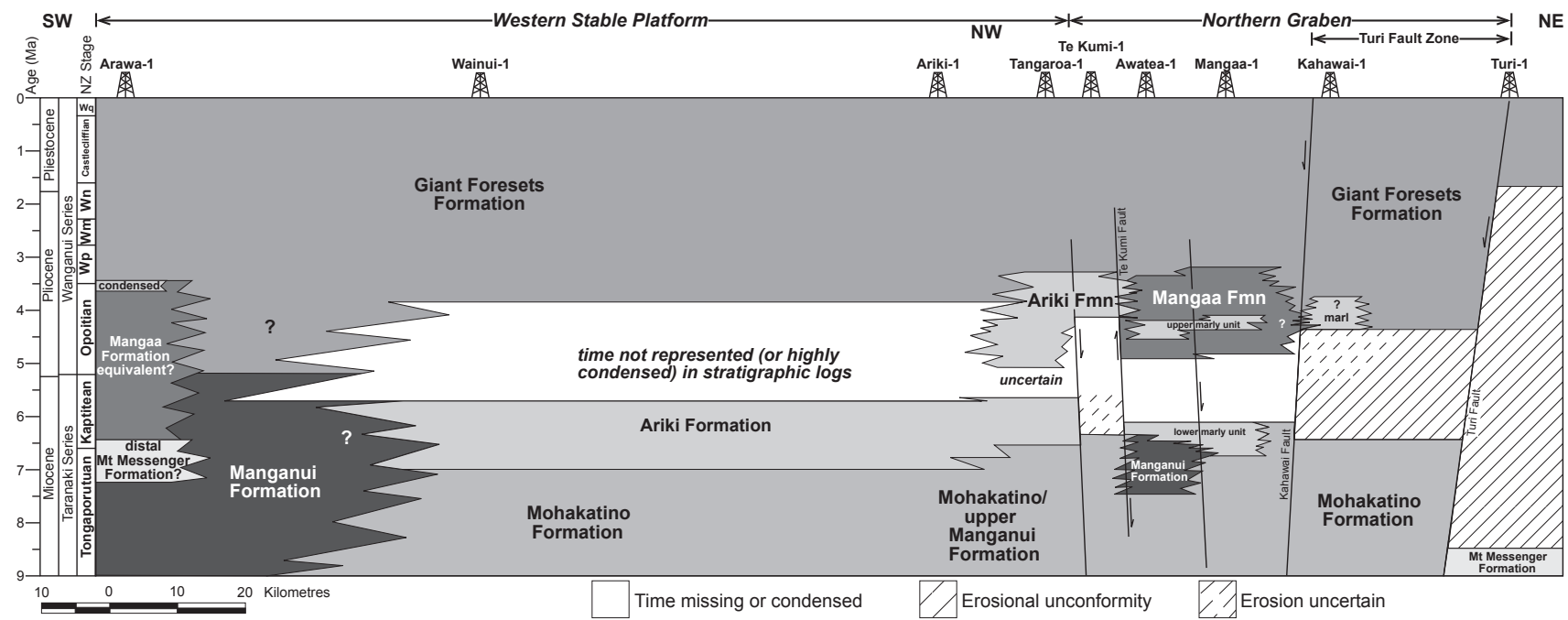

Fig. 8 Chronostratigraphic panel illustrating the stratigraphic relationships between the late Miocene-Pleistocene formations within northern Taranaki Basin. Note particularly the distribution of the Ariki Formation and related marly units, and the ages of the bases of the Mangaa and Giant Foresets Formations. The unconformity east of the Turi Fault Zone results from uplift and erosion. New Zealand stage abbreviations: Wp, Waipipian; Wm, Mangapanian; Wn, Nukumaruan; Wq, Haweran.

that most of the uncertainty is due to the inherent limitations of determining a biostratigraphy from well cuttings.

The application of the late Neogene integrated time-stratigraphic framework to the northern Taranaki Basin has allowed us to produce a series of isopach maps that show a sensible pattern of depocentre migration in response to progradation of a continental margin wedge across an actively extending asymmetrical graben and onto the Western Stable Platform.

\section{ACKNOWLEDGMENTS}

We thank Bruce Hayward and Martin Crundwell for their kind assistance with foraminiferal identifications and helpful suggestions during this investigation, and George Scott and Bruce Hayward for their review of the manuscript and useful suggestions for improvement. We also thank Geosphere Exploration Ltd (Lower Hutt, New Zealand) for access to time-depth conversions for northern Taranaki Basin. We acknowledge the New Zealand Foundation for Research, Science and Technology for research funding (contracts: UOW608 and UOWX0301).

\section{REFERENCES}

ARCO Petroleum NZ Inc. 1989. Final report of operations and field work, Marine Geophysical Survey, Offshore Taranaki. PPL38446. Ministry of Commerce New Zealand unpublished petroleum report 1475 (AR89-446-108).

ARCO Petroleum NZ Inc. 1990. Final report of operations and field work, Taranaki Basin. PPL38445. 1990 seismic survey. Ministry of Commerce New Zealand unpublished petroleum report 1628 (AR90-445-103).

Armentrout JM 1991. Paleontologic constraints on depositional modeling: examples of integration of biostratigraphy and seismic stratigraphy, Pliocene-Pleistocene, Gulf of Mexico. In: Weimer P, Link MH ed. Seismic facies and sedimentary processes of submarine fans and turbidite systems. New York, Springer-Verlag. Pp. 137-170.
Armstrong PA, Chapman DS, Funnell RH, Allis RG, Kamp PJJ 1996. Thermal modelling and hydrocarbon generation in an active-margin basin: the Taranaki Basin, New Zealand. American Association of Petroleum Geologists Bulletin 80: 1216-1241.

Bé AWH 1977. An ecological, zoographic and taxonomic review of recent planktonic foraminifera. In: Ramsay ATS ed. Oceanic micropalaeontology. London, Academic Press. Pp. 1-100.

Bé AWH, Tolderlund DS 1971. Distribution and ecology of living planktonic foraminifera in surface waters of the Atlantic and Indian Oceans. In: Funnell BM, Reidel WR ed. The micropalaeontology of oceans. Great Britain, Cambridge University Press. Pp. 105-149.

Beggs JM 1990. Seismic stratigraphy of the Plio-Pleistocene Giant Foresets, Western Platform, Taranaki Basin. 1989 NZ Oil Exploration Conference proceedings. Wellington, Ministry of Commerce. Pp. 201-207.

Beu AG 2001. Local stages to be used for the Wanganui Series (Pliocene-Pleistocene), and their means of definition. New Zealand Journal of Geology and Geophysics 44: 113-125.

Cooper RA ed. 2004. The New Zealand geological timescale. Institute of Geological \& Nuclear Sciences Monograph 22. $284 \mathrm{p}$.

Cross TA, Lessenger MA 1988. Seismic stratigraphy. In: Wetherill GW, Albee AL, Stehli FG ed. Annual Review of Earth and Planetary Sciences 16: 319-354.

Crundwell MP, Scott GH, Strong CP 1992. Biostratigraphy of Arawa-1 offshore petroleum exploration well, North Taranaki Basin. New Zealand Department of Scientific and Industrial Research (Geology and Geophysics). Contract report 1992/18.

Dowsett HJ 1988. Diachrony of late Neogene microfossils in the Southwest Pacific ocean: application of the graphic correlation method. Paleoceanography 3(2): 209-222.

Emery D, Myers KJ ed. 1996. Sequence stratigraphy. Oxford and Northampton, Great Britain, Blackwell Science. 297 p.

Geco New Zealand 1987. Offshore Taranaki reprocessing report. New Zealand, Ministry of Commerce unpublished petroleum report 1399 (NM16). 
Hansen RJ 2003. Characteristics and evolution of a dynamic prograding continental margin: the late Neogene Giant Foresets Formation, northern Taranaki Basin, New Zealand. Unpublished $\mathrm{PhD}$ thesis, University of Waikato, Hamilton, New Zealand. 414 p.

Hansen RJ, Kamp PJJ 2004a. Re-evaluation of the late Neogene biostratigraphy of Arawa-1, Ariki-1, Kora-1, and Wainui-1, and integrated seismic and biostratigraphic correlation of 11 wells, northern Taranaki Basin. Wellington, Ministry of Economic Development, Crown Minerals. Petroleum Report PR2938.

Hansen RJ, Kamp PJJ 2004b. Late Miocene to early Pliocene stratigraphic record in northern Taranaki Basin: condensed sedimentation ahead of Northern Graben extension and progradation of the modern continental margin. New Zealand Journal of Geology and Geophysics 47: 645-662.

Hayward BW 1983. Planktic foraminifera (Protozoa) in New Zealand water: a taxonomic review. New Zealand Journal of Zoology 10: 63-74.

Hayward BW 1986. A guide to paleoenvironmental assessment using New Zealand Cenozoic foraminiferal faunas. New Zealand Geological Survey Report PAL 109. Lower Hutt, New Zealand Geological Survey, Department of Scientific and Industrial Research.

Hornibrook NdeB 1982. Late Miocene to Pleistocene Globorotalia (Foraminiferida) from DSDP Leg 29, Site 284, Southwest Pacific. New Zealand Journal of Geology and Geophysics 25: 83-99.

Hoskins RH 1990. Planktic foraminiferal correlation of the Late Pliocene to Early Pleistocene of DSDP Sites 284 and 593 (Challenger Plateau) with New Zealand Stages. New Zealand Geological Survey Report PAL 149. Lower Hutt, New Zealand Geological Survey, Department of Scientific and Industrial Research.

Hoskins RH, Raine 1984. Biostratigraphy of Taimana-1. New Zealand Geological Survey Report 74.

Kamp PJJ, Green PF, White SH 1989. Fission track analysis reveals character of collisional tectonics in New Zealand. Tectonics 8: 169-195.

Kamp PJJ, Vonk AJ, Bland KJ, Hansen RJ, Hendy AJW, McIntyre AP, Ngatai M, Cartwright SJ, Hayton S, Nelson CS 2004. Neogene stratigraphic architecture and tectonic evolution of Wanganui, King Country, and eastern Taranaki Basins, New Zealand. New Zealand Journal of Geology and Geophysics 47: 625-644.

King PR, Thrasher GP 1996. Cretaceous-Cenozoic geology and petroleum systems of the Taranaki Basin, New Zealand. Institute of Geological \& Nuclear Sciences Monograph 13. 243 p., 6 enclosures.

McIntyre AP 2001. Geology of Mangapanian (late Pliocene) strata, Wanganui Basin: lithostratigraphy, paleontology and sequence stratigraphy. Unpublished $\mathrm{PhD}$ thesis, The University of Waikato, Hamilton, New Zealand. 431 p.

Mitchum RM Jr, Vail PR, Thompson S III 1977. Seismic stratigraphy and global changes in sea level. Part 6: Stratigraphic interpretation of seismic reflection patterns in depositional sequences: the depositional sequence as a basic unit for stratigraphic analysis. In: Payton CE ed. Seismic stratigraphy - applications to hydrocarbon exploration. American Association of Petroleum Geologists Memoir 26: 117-133.

Morgans HEG, Scott GH, Beu AG, Graham IJ, Mumme TC, St George W, Strong CP 1996. New Zealand Cenozoic timescale (version 11/96). Institute of Geological \& Nuclear Sciences Science Report 96/38. 12 p.
Murray JW 1976. A method of determining proximity of marginal seas to an ocean. Marine Geology 22: 103-119.

Murray JW 1991. Ecology and distribution of planktonic foraminifera. In: Lee JJ, Anderson OR ed. Biology of foraminifera. London, Academic Press. Pp. 254-284.

North American Commission on Stratigraphic Nomenclature 1983. North American Stratigraphic Code. American Association of Petroleum Geologists Bulletin 67(5): 841-875.

Petrocorp Exploration Ltd 1995a. Offshore 2D seismic survey, 1995/1996. P95 Lines. PPL38455, PPL38456, PPL38457, PPL38458, PPL38459. Wellington, New Zealand, Ministry of Commerce unpublished petroleum report 2261.

Petrocorp Exploration Ltd 1995b. 1995 offshore reprocessing programme. PPL38455, PPL38456, PPL38457, PPL38458 and PPL38459. Wellington, New Zealand, Ministry of Commerce unpublished petroleum report 2271 (NM17).

Pilaar WFH, Wakefield LL 1978. Structural and stratigraphic evolution of the Taranaki Basin, offshore North Island, New Zealand. APEA Journal 18(1): 93-101.

Sabaa AT 2000. Pliocene foraminifieral biostratigraphy and paleoceanography of ODP Site 1125, eastern New Zealand. Unpublished MSc thesis, University of Auckland, Auckland, New Zealand. 107 p.

Scott GH, Bishop S, Burt BJ 1990. Guide to some Neogene Globorotalids (Foraminiferida) from New Zealand. New Zealand Paleontological Bulletin 61. $135 \mathrm{p}$.

Scott GH, King PR, Crundwell MP 2004. Recognition and interpretation of depositional units in a late Neogene progradational shelf margin complex, Taranaki Basin, New Zealand: foraminiferal data compared with seismic facies and wireline logs. Sedimentary Geology 164: 55-74.

Shell BP and Todd Oil Services Ltd 1974. Seismic programme 1976, PPL38006 PPL38004 PPL38007. New Zealand Ministry of Commerce unpublished petroleum report 668 (HF11x, HF510, HF 1100).

Soenander HB 1992. Seismic stratigraphy of the Giant Foreset Formation, offshore North Taranaki-Western Platform. 1991 New Zealand Oil Exploration Conference proceedings. Wellington, Ministry of Commerce. Pp. 207-233.

Strong CP, Waghorn DB, Cooper RA, Crampton JS, Morgans HEG, Raine JI 1996. Biostratigraphy of Awatea-1 offshore petroleum exploration drillhole, North Taranaki Basin. Institute of Geological \& Nuclear Sciences Client Report 53652A.10. Lower Hutt, New Zealand, Institute of Geological \& Nuclear Sciences.

Turner GM, Kamp PJJ 1990. Paleomagnetic location of the Jaramillo subchron and Brunhes-Matuyama transition in the Castlecliffian Stratotype section, Wanganui Basin, New Zealand. Earth and Planetary Science Letters 100: 42-50.

Turner GM, Kamp PJJ, McIntyre AP, Hayton S, McGuire D, Wilson GS 2005. A coherent middle Pliocene magnetostratigraphy, Wanganui Basin, New Zealand. Journal of the Royal Society of New Zealand 35: 197-227.

Vail PR 1987. Seismic stratigraphy interpretation using sequence stratigraphy. Part I: Seismic stratigraphy interpretation procedure. In: Bally AW ed. AAPG atlas of seismic stratigraphy, vol. 1. American Association of Petroleum Geologists Studies in Geology 27: 1-10. Tulsa, American Association of Petroleum Geologists.

Waghorn DB, Strong, CP, Raine JI, Crampton JS 1996. Biostratigraphic review of the late Miocene and Pliocene of the Mangaa-1, Kahawai-1, Te Kumi-1, Tangaroa-1, and Kora-1 wells, offshore Taranaki Basin. New Zealand, Ministry of Commerce unpublished petroleum report 2417. 